УДК 352.07

https://doi.org/10.34142/24130060.2020.20.1.08

\title{
ГЛОБАЛЬНИЙ ПОЛІТИЧНИЙ ПРОСТІР: ПОСТМОДЕРНІСТСЬКИЙ ПОГЛЯД
}

\author{
Ю. В. Зайончковський \\ Харківський національний університет будівництва і архітектури
}

\section{Л. В. Фірсова}

Харківський національний технічний університет сільського господарства імені Петра Василенка

Стаття присвячена специфіиі постмодерністського погляду на зміст характеристики «глобальний» по відношенню до сучасного політичного простору. Використано характерне для постмодерністської методології поєднання спеціальних підходів - транснаціонального, мережсевого, акторного $i$ комунікативного. Запропоновано параметри для аналізу сучасного політичного простору. Глобальний політичний простір в парадигмі постмодернізму описано як амбівалентне метафоричне поняття, щцо характеризує суперечливість світового політичного процесу в умовах глобалізації.

Ключові слова: глобалізація, громадянське суспільство, політична еліта, політичний простір, постмодернізм.

\section{ГЛОБАЛЬНОЕ ПОЛИТИЧЕСКОЕ ПРОСТРАНСТВО: ПОСТМОДЕРНИСТСКИЙ ВЗГЛЯД}

\author{
Ю. В. Зайончковский, Л. В. Фирсова
}

Статья посвящена специфике постмодернистского взгляда на содержание характеристики «глобальное» по отношению $\kappa$ современному политическому пространству. Использовано характерное для постмодернистской методологии сочетание специальных подходов - трансначионального, сетевого, акторного и коммуникативного. Предложены параметры для анализа современного политического пространства. Глобальный политическое пространство в парадигме постмодернизма описано как амбивалентное метафорическое понятие, характеризующее противоречивость мирового политического процесса в условиях глобализации.

Ключевые слова: глобализачия, гражданское общество, политическая элита, политическое пространство, постмодернизм.

\section{GLOBAL POLITICAL SPACE: A POSTMODERNIST VIEW}

\section{Y. Zayonchkovsky, L. Firsova}

The article is devoted to the specifics of the postmodernist view of the content of the characteristic «global» in relation to the modern political space. The combination of special approaches typical for postmodernist methodology - transnational, network, actor and 
communicative - is used. Within the paradigm of postmodernism, we can distinguish two research areas in the study of political space in the context of globalization.

According to the first, the political space is seen as a single, common and universal. According to the second, the political space is discrete, heterogeneous and contradictory.

Global political space in the paradigm of postmodernism is described as an ambivalent metaphorical concept that characterizes the contradictions of the world political process in the context of globalization. However, despite all the arguments in favor of the formation of a global political space, the latter cannot yet be described as a single or common. Cultural, historical, religious, ideological differences do not hinder economic globalization, but make it impossible to build a similar political space based on universal values. The global elite is predominantly business rather than political. The political elite, in turn, is underdeveloped institutionally, lacks structures similar to the world government, and its decisions are volatile, uncertain, accountable, and unable to balance the economic benefits of globalization with the social needs of civil society. Global civil society consists of the internationalization of many local, national and international non-governmental movements. Their political solidarity is situational, shortterm and unstable. Political activity is vulnerable due to state censorship of not only traditional but also new media, blocking of opposition parties and social movements, and repression of citizens who openly express their political will. Harmonization of international political discourse is hindered by the impossibility of rational analysis of a wide array of political information for the majority of citizens, which leads to communicative inconsistency of participants in the world political process.

Keywords: globalization, civil society, political elite, political space, postmodernism.

Постановка проблеми. В умовах глобалізації на зміну традиційним формамтериторіальної організації просторів приходять інші їх різновиди. Стійкий інтерес до проблематики політичного простору, який спостерігається з середини минулого століття, призвів до появи його нових інтерпретацій - географічної, соціологічної, антропологічної та комунікативної (Denysenko, 2015b). Незважаючи на специфіку кожного підходу, вчені одностайно характеризують сучасний політичний простір як «єдиний», або «загальний». Поняття «глобальний» продовжує в цьому плані синонімічний ряд, побудований на ідеї єдності і спільності.

Аналіз актуальних досліджень. У рамках парадигми постмодернізму можна виділити два дослідних напрямки у вивченні політичного простору в умовах глобалізації.

Відповідно до першого, політичний простір розглядається як єдине, загальне і універсальне. Згідно з другим, політичний простір має дискретний, неоднорідний і суперечливий характер. Так, «єдині / загальні простори» описують відносини між країнами СНД і співробітництво країн Свросоюзу; Північна Америка та Західна Свропа називаються «прообразом єдиного 
політико-економічного простору». Однак поряд з тенденцією до уніфікації вчені-постмодерністи відзначають антиномічну ій тенденцію дискретності глобальних і локальних процесів, мозаїчності картини сучасного світу. Простір епохи постмодерну - метафора, яка об’єднує сфери діяльності, види зайнятості, програми дій, що мають свої межі подібно кордонам фізичного простору. Це соціальні конструкти, які створюють обмеження або можливості участі в політиці, економіці або суспільному житті. Постмодерністський простір багатовимірний, мінливий i залежний від обставин. Слід говорити про безліч просторів - пересічних, які збігаються, існують у відносинах протиріччя або антагонізму. Простір може інтерпретуватися по-різному, мати різні значення в різних обставинах для різних учасників (Denysenko, 2015b)

Мета дослідження. Дана стаття присвячена розгляду постмодерністському погляду на політичний простір i, зокрема, на те, яке відображення в ньому знаходять феномени інформаційного суспільства дискретність і мозаїчність.

Виклад основного матеріалу. Вибір параметрів для аналізу сучасного політичного простору пов'язаний з вищеназваними дослідними підходами і має на меті виявлення специфіки «глобальних» феноменів, а саме: глобальних інформаційно-комунікаційних мереж, глобальних політичних акторів, засобів здійснення глобальної політичної комунікації, глобальної мобільності і глобального політичного процесу. Такими параметрами, на наш погляд, можуть служити:

- наявність політико-комунікативної єдності;

- рівень глобальної мобільності;

- ступінь розвитку глобальної політичної еліти;

- сформованість глобального громадянського суспільства;

- охоплення політичної сфери мовою міжнародного спілкування.

Як відомо, політичне розуміння глобалізації пов’язане зі сприйняттям явищ суспільного життя через призму інформаційно-комунікаційної 
складової (Denysenko, 2013). «Мережа» - ключовий термін глобалізації, в рівній мірі застосовний до міжконтинентального поширення телекомунікації, масового туризму i масової культури, транскордонних ризиків великих підприємств, торгівлі зброєю, екологічних впливів світового масштабу, міжнародного співробітництва урядових або неурядових організацій (Habermas, 2005, s. 279-280). Саме мережеву модель називають однією 3 організаційних форм участі асоціативних (конфесійних, етнічних, ділових і ін.) i неассоціативних груп інтересів в глобальних процесах і зовнішній політиці (Denysenko, 2015a). Мережі грають важливу роль у формуванні ідеологічного сектора глобального співтовариства, оскільки є інструментом актуалізації локальних проблем i їх просування на глобальний рівень міжнародного обговорення. Іншими словами, відбувається становлення порядку денного світової політики, що знаходиться по той бік традиційної проблематики міждержавних взаємодій і володіє глобальним за охопленням форматом. Одним 3 головних мережевих ефектів $\epsilon$ істотне зниження значення вертикальних зв’язків при одночасному посиленні ролі горизонтальних. У політичній практиці це означає виклик ієрархічно організованим політичним структурам - в першу чергу державам i політичним партіям (Voronianskyi, 2012b). У сучасному світі традиційна ієрархічна модель управління зазнала значних змін на користь змішання традиційних, нових і гібридних процесів на самих різних рівнях: локальному, національному, наднаціональному. Індивіди стають членами міжнародних мереж, минаючи посередництво національних інститутів; невеликі локальні групи безпосередньо взаємодіють із транснаціональними структурами; регіональні об’єднання вступають в партнерські зв'язки за кордоном без втручання відповідних держав (Anderson, 1996, p. 150).

Через взаємодію і протидію національних, регіональних, релігійних або професійних мереж солідарності створюються нові масові форми політичної участі, наприклад транснаціональний інтернет-активізм. (Tkacheva and etc., 
2013, р. 6). Вони вже впливають на політичну систему і формування політичного простору, у результаті чого:

- видозмінюються просторові детермінанти політичної спільноти;

- політичні інтеракції набувають багаторівневий характер;

- знижується важливість фізичної території як сховища політичного значення;

- розширюються можливості індивідів в отриманні доступу до інформації;

- гегемонія певного політичного актора змінюється мережевою рівністю безлічі політичних акторів;

- держава втрачає здатність повністю контролювати дискурсивні практики публічної сфери.

Ще одним із проявів глобалізації визнають посилення просторової мобільності населення і залучення все більшої кількості громадян до процесів міжнародної міграції. Основна маса досліджень глобалізації присвячена відкритості і проникності кордонів. Говорити про глобальні політичні транзакції, хоча і в найзагальнішому сенсі, дозволяє активний рух інформації, фінансів, фізичних об'єктів, людей i інших матеріальних i нематеріальних одиниць через державні кордони. При цьому міжнародна діяльність може включати всі види глобальних транзакцій політичного характеру, вимагаючи координації інформаційних, фінансових, людських потоків і фізичних ресурсів. Так звана глобальна мобільність $\epsilon$ в сучасному світі базовою характеристикою людського існування. Прихильники позитивного впливу глобалізації стверджують, що простір втрачає обмежуючий вплив на глобально мобільних особистостей, добровільних учасників міжкультурної взаємодії. Мобільним особистостям приписується легкість адаптації до нових умов: просторових, темпоральних, інформаційних, культурних, ідеологічних.

Формування глобального політичного простору сприяє становленню глобальної політичної еліти. Спосіб життя політичної та економічної еліт в 
різних країнах стає ближче один до одного, все більше відділяючись від проблем місцевого населення. Представники цього кола $\epsilon$ носіями i провідниками глобальних поглядів на світовій політичній арені. Інтенсивна мобільність, космополітичний спосіб життя, високі доходи і розвинена класова самосвідомість забезпечують перехід міжнародної еліти до глобального управління і прийняття рішень на наднаціональному рівні. Ресурси, що знаходяться в іiі руках, надають практично необмежені можливості для проведення потрібної політики та послідовного усунення усіляких перешкод, включаючи зміну політичної влади в будь-якій країні, де інтереси національної еліти розходяться 3 інтересами еліти глобальної (Voronianskyi, 2019).

Велика увага в постмодерністських дослідженнях глобального політичного простору приділяється проблемі становлення глобального громадянського суспільства. Вперше цей термін стали використовувати в контексті діяльності Організації Об’єднаних Націй. Досягнення глобальних цілей - боротьба 3 несправедливістю, підвищення безпеки людства, створення більш гармонійного світопорядку і посилення впливу країн Півдня в глобальній полеміці - на думку ООН, можливе через налагодження продуктивної взаємодії 3 громадянським суспільством в глобальному масштабі. Дана сфера моделюється діяльністю різного роду неурядових організацій по всьому спектру міжнародної правозахисної проблематики, питань сприяння демократичним перетворенням, екологічним проблемам та ін.. Конкретизуючи різницю між громадянським суспільством і глобальним громадянським суспільством, відзначимо, що громадянське суспільство включає політичні, культурні та громадські організації сучасного суспільства, які автономні від держави, але регулюють відносини між державою і суспільством. У свою чергу, глобальне громадянське суспільство формується як результат діяльності локальних, національних і міжнародних неурядових організацій 3 безлічі питань: захист світу, навколишнього середовища, знедолених верств населення, громадян 3 розумовими та 
фізичними вадами, бездомних, прав тварин, людей нетрадиційної сексуальної орієнтації, націоналізм, популізм, фемінізм, анархізм, синтетичні релігійні культи, політичні процеси в країнах, що розвиваються та ін. Незважаючи на всю різноманітність, ці рухи об’єднані пошуками нового політичного вираження і нового простору для політичних дій. Фактично ми спостерігаємо нове явище - формування світової громадської думки, яке визначає політичний порядок денний і позначає комплекс норм і цивільних вимог, що виходять за межі національних кордонів.

У той же час сучасний політичний простір виступає носієм характеристик, що не дозволяють вважати його єдиним і універсальним. Поперше, слід поставити під сумнів політико-комунікативну єдність глобального простору. Нагадаємо головне протиріччя епохи постмодерну: політична глобалізація не відповідає економічній. Глобальний ринок не привів до появи адекватних інтеграційних політичних процесів. У свою чергу, ефективність глобального управління передбачає опору на загальну систему основоположних цінностей, загальнолюдську мораль і дієздатне глобальне право (Benoit and Laver, 2012).

Культурні відмінності, що обумовлюють тяжіння держав до певного типу політичного устрою, сильний вплив ідеології і релігії не дозволяють говорити про перспективу створення глобального політичного простору. У той час як економіка, торгівля, засоби комунікації та культура стають більш глобальними за своїм характером, представницька демократія по суті залишається національною та локальною. Політика в глобальному масштабі відстає від економіки: прийняті на міжнародному рівні рішення вимагають розробки міцної демократичної основи для глобального управління, тобто, підзвітності громадянам. Це, по-перше.

По-друге, крім інтеграційних явищ, на зразок описаної вище глобальної мобільності, має місце i нульова мобільність. Обумовлена як локальна скутість, вкрай низька або нульова ступінь реальної і віртуальної мобільності ускладнює міжнародні міграції. Назвемо такі «бар’єри» вільного 
пересування, як фінансові проблеми, відсутність ІТ-компетенцій, неволодіння іноземними мовами, зокрема англійською (Tkacheva and etc., 2013, р. 6). Подібні проблеми призводять до того, що люди знаходяться на периферії глобального простору, вимушено прив'язані до території, і зв’язок 3 простором може сприйматися як нездоланна перешкода.

По-третє, незважаючи на процес формування глобальної еліти, іiі не слід розглядати як еліту виключно політичну. Міжкультурні процеси більшою мірою охопили ділову еліту - представників фінансової, телекомунікаційної та енергетичної галузей, інтелектуальну і культурну еліти, еліти спецслужб, організованої злочинності і інших функціональних сегментів. Крім того, глобальна еліта слабо розвинена інституційно - відсутні структури, які можна було хоча б приблизно уподібнити «світовому уряду». Додамо, що в умовах зниження ролі національної держави, зміни уявлень про керованість політичною ситуацією в еліти посилюється почуття нестабільності і невпевненості. Її рішенням притаманна ослаблена відповідальність, вони погано піддаються парламентському i громадянському контролю, не забезпечують баланс між перевагами економічної глобалізації та соціальною справедливістю, між «включенністю» в міжнародні процеси і збереженням пріоритетності національних інтересів.

По-четверте, дослідження показують, що глобальне громадянське суспільство поки що також далеке від планетарного охоплення. Експертні оцінки проектної активності ООН і досвіду глобальних протестних рухів дозволяють говорити про глобальне громадянське суспільство як про множинність громадянських суспільств окремих країн з виходом на високий рівень інтернаціоналізації. Для них характерний новий тип солідарності маневрена солідарність: ситуативне створення короткочасних нестійких зв'язків з актуального політичного приводу. При такому типі солідарності не вибудовуються міцні формально-структурні взаємозв’язки 3 довготривалою перспективою (Voronianskyi, 2014). 
Злагодженості політичних дій громадянського суспільства заважають обмеження, пов’язані 3 рівнем поширення Інтернету i специфікою політичних режимів (Tkacheva and etc., 2013, р. 39-40). Чим більшим обмеженням піддається інтернет-сфера, тим проблематичніше політична онлайн-мобілізація аудиторії. Фільтрація онлайн-трафіку владою перешкоджає отриманню лідерами громадської думки необхідної інформації і ініціювання політичної дискусії серед інтернет-користувачів; репресивні заходи значно обмежують вираз політичної волі і організацію колективних дій. Всі ці обмеження роблять взаємозв'язок між онлайн- i офлайнмобілізацією нестійкою, а політичні дії - спонтанними.

Аномія в полі публічної політичної комунікації проявляє себе у вигляді нездатності масової свідомості громадян адекватно реагувати на неконтрольований потік інформації i робити обгрунтований вибір; в неготовності громадян в умовах соціального, економічного, політичного кризи приймати і засвоювати нові правила соціального життя; у відсутності громадянської ініціативи. У такій політичній комунікації відбувається неузгодженість учасників комунікативного процесу i не приймаються колективно-обов'язкові рішення (Voronianskyi, 2012a).

Висновки і перспективи подалыших досліджень. Незважаючи на всі аргументи на користь становлення глобального політичного простору, останній поки не може бути охарактеризований як єдиний або загальний. Культурні, історичні, релігійні, ідеологічні відмінності не перешкоджають економічної глобалізації, але роблять неможливим побудову аналогічного політичного простору, заснованого на універсальні цінності. Глобальна еліта має переважно діловий, а не політичний характер. Політична еліта, в свою чергу, слабо розвинена інституційно, в іiі складі відсутні структури, подібні світовому уряду, а іiі рішення відрізняються нестабільністю, невпевненістю, недостатньою відповідальністю, нездатністю забезпечити баланс між економічними вигодами глобалізації та соціальними потребами громадянського суспільства. Глобальне громадянське суспільство 
складається з інтернаціоналізації діяльності безлічі локальних, національних i міжнародних неурядових рухів. Їх політична солідарність ситуативна, короткострокова i нестійка. Політична активність $є$ вразливою через державну цензуру не лише традиційних, але й нових медіа, блокування опозиційних партій і громадських рухів, репресії щодо громадян, які відкрито виявляють свою політичну волю. Гармонізації міжнародного політичного дискурсу перешкоджає неможливість раціонального аналізу широкого масиву інформації політичного характеру для більшості громадян, що призводить до комунікативної неузгодженості учасників світового політичного процесу.

\section{ЛІТЕРТУРА}

1. Воронянський, О.В., 2012а. Політична трансформація в контексті проблеми перерозподілу ресурсів. Вісник Харківського національного університету імені В.Н. Каразіна. Питання політології, 20(1007), c. 51-57.

2. Воронянський, О. В., 2012b. Роль національного суверенітету в легітимації державної влади. Актуальні проблеми державного управління, 2, с. 216-221.

3. Воронянський, О. В., 2014. Політичні інститути: механізм формування в конкурентному середовищі. Сучасне суспільство: політичні науки, соціологічні науки, культурологічні науки, 1, с. 15-28.

4. Воронянський, О.В., $2019 . \quad$ Проблеми трансформації політичної суб'єктності в постіндустріальному суспільстві. Сучасне суспільство: політичні науки, сочіологічні науки, культурологічні науки, 18(2), с. 3747.

5. Денисенко, І. Д., 2013. Соціальні мережі в контексті соціокультурного підходу: евристичний потенціал дослідження. Вісник ХНПУ імені Г. С. Сковороди «Філософія», 40, с. 22-28.

6. Денисенко, І. Д., 2015а. Моделювання поведінки особистості в сучасних соціокультурних контекстах: методологічні засади та перспективи. Науковий вісник. "Філософія», 45(I), с. 205-214.

7. Денисенко, I. Д., 2015b. Теорія соціального простору: евристичний потенціал щодо соціально-політичних

\section{REFERENCES}

1. Voronianskyi, O. V., 2012a. Politychna transformatsiia $\mathrm{V}$ konteksti problemy pererozpodilu resursiv. Visnyk Kharkivskoho natsionalnoho universytetu imeni V.N. Karazina. Pytannia politolohii, 20(1007), s. 51-57.

2. Voronianskyi, O. V., 2012b. Rol natsionalnoho suverenitetu $\mathrm{V}$ lehitymatsii derzhavnoi vlady. Aktualni problemy derzhavnoho upravlinnia, 2, s. 216-221.

3. Voronianskyi, O. V., 2014. Politychni instytuty: mekhanizm formuvannia $\mathrm{V}$ konkurentnomu seredovyshchi. Suchasne suspilstvo: politychni nauky, sotsiolohichni nauky, kulturolohichni nauky, 1, s. 15-28.

4. Voronianskyi, O. V., 2019. Problemy transformatsii politychnoi subiektnosti V postindustrialnomu suspilstvi. Suchasne suspilstvo: politychni nauky, sotsiolohichni nauky, kulturolohichni nauky, 18(2), s. 3747.

5. Denysenko, I. D., 2013. Sotsialni merezhi v konteksti sotsiokulturnoho pidkhodu: evrystychnyi potentsial doslidzhennia. Visnyk KhNPU imeni H. S. Skovorody «Filosofiia», 40, s. 22-28.

6. Denysenko, I. D., 2015a. Modeliuvannia povedinky osobystosti $\mathrm{v}$ suchasnykh sotsiokulturnykh kontekstakh: metodolohichni zasady ta perspektyvy. Naukovyi visnyk. «Filosofiia», 45(I), s. 205214.

7. Denysenko, I. D., 2015b. Teoriia sotsialnoho prostoru: evrystychnyi potentsial shchodo sotsialno-politychnykh doslidzhen. Suchasne 
досліджень. Сучасне суспільство: політичні науки, сочіологічні науки, культурологічні науки, 2(2), с. 27-37.

8. Хабермас Ю., 2005. Постнациональная констелляция и будущее демократии. Перевод с немецкого Б. М. Скуратова. В: А. В. Денежкина. Политические работь. Москва: Праксис, с. 269-340.

9. Anderson, J., 1996. The Shifting Stage of Politics: New Medieval and Postmodern Territorialities? Environment and Planning D: Society and Space, 14 (2), p. 133-153.

10. Benoit K.,\& Laver M., 2012. The Dimensionality of Political Space: Epistemological and Methodological Considerations. European Union Politics. 13 (2), p. 194-218.

11. Tkacheva O., Lowell H. Schwartz, Martin C. Libicki, Julie E. Taylor, J. Martini and C. Baxter, 2013. Internet Freedom and Political Space. Santa Monica, CA: RAND. suspilstvo: politychni nauky, sotsiolohichni nauky, kulturolohichni nauky, 2(2), s. 27-37.

8. Habermas Yu., 2005. Postnacionalnaya konstellyaciya i budushee demokratii. Perevod s nemeckogo B. M. Skuratova. V: A. V. Denezhkina. Politicheskie raboty. Moskva: Praksis, s. 269-340.

9. Anderson, J., 1996. The Shifting Stage of Politics: New Medieval and Postmodern Territorialities? Environment and Planning D: Society and Space, 14 (2), r. 133-153.

10. Benoit K., \& Laver M., 2012. The Dimensionality of Political Space: Epistemological and Methodological Considerations. European Union Politics. 13 (2), r. 194-218.

11. Tkacheva O., Lowell H. Schwartz, Martin C. Libicki, Julie E. Taylor, J. Martini and C. Baxter, 2013. Internet Freedom and Political Space. Santa Monica, CA: RAND.

\section{Інформація про авторів}

Зайончковський Юрій Валентинович - кандидат історичних наук, доцент, доцент кафедри українознавства та євроінтеграції Харківського національного університету будівництва та архітектури; $\quad$ e-mail: $\quad$ zyvkharkov@gmail.com; ORCID: http://orcid.org/00000002-7457-1792.

Фірсова Людмила Володимирівна - кандидат філософських наук, доцент, професор кафедри ЮНЕСКО «Філософія людського спілкування» та соціально-гуманітарних дисциплін Харківського національного технічного університету сільського господарства імені Петра Василенка; e-mail: firsova_l@ukr.net; ORCID: http://orcid.org/0000-0002-52528291.

Стаття надійшла до редакції: 26.11.2019 р. Прийнята до друку: 18.12.2019 р. 